19 Revue d'histoire du XIXe siècle

Société d'histoire de la révolution de 1848 et des

révolutions du XIXe siècle

17 | 1998

Les foules au XIXe siècle

\title{
La foule en colère : les mineurs et la grève au XIXe siècle
}

\section{Diana Cooper-Richet}

\section{OpenEdition}

\section{Journals}

Electronic version

URL: http://journals.openedition.org/rh19/141

DOI: $10.4000 /$ rh19.141

ISSN: $1777-5329$

\section{Publisher}

La Société de 1848

\section{Printed version}

Date of publication: 1 December 1998

ISSN: 1265-1354

\section{Electronic reference}

Diana Cooper-Richet, "La foule en colère : les mineurs et la grève au XIXe siècle ", Revue d'histoire du XIXe siècle [Online], 17| 1998, Online since 10 September 2008, connection on 20 April 2019. URL http://journals.openedition.org/rh19/141; DOI : 10.4000/rh19.141

This text was automatically generated on 20 April 2019

Tous droits réservés 


\title{
La foule en colère : les mineurs et la grève au XIXe siècle
}

\author{
Diana Cooper-Richet
}

\section{ABSTRACTS}

No abstract available by now

Pas de résumé disponible actuellement

INDEX

Mots-clés: Foules, Mineurs, Grève 